\begin{tabular}{|c|c|c|c|}
\hline Case Reports in & \multicolumn{2}{|c|}{ Case Rep Gastroenterol 2019;13:85-88 } & \multirow{3}{*}{$\begin{array}{l}\text { Karger } \\
\text { Openaccess }\end{array}$} \\
\hline Gastroenterology & $\begin{array}{l}\text { DOI: } 10.1159 / 000493920 \\
\text { Published online: February 20, } 2019\end{array}$ & $\begin{array}{l}\text { (c) } 2019 \text { The Author(s) } \\
\text { Published by S. Karger AG, Basel } \\
\text { www.karger.com/crg }\end{array}$ & \\
\hline & $\begin{array}{l}\text { This article is licensed under the } \\
\text { International License (CC BY-NC) } \\
\text { Usage and distribution for commercia }\end{array}$ & $\begin{array}{l}\text { nons Attribution-NonCommercial } 4.0 \\
\text { ger.com/Services/OpenAccessLicense) } \\
\text { uires written permission. }\end{array}$ & \\
\hline
\end{tabular}

\title{
Signet-Ring Cell Carcinoma Presenting as Hematochezia in a Patient with Crohn's Disease
}

\author{
Jiazuo H. Feng ${ }^{a} \quad$ Christopher M. Navas $^{a} \quad$ Andrea M. Olofson ${ }^{b}$ \\ Nayla Ahmed ${ }^{\mathrm{a}}$ \\ aDepartment of Internal Medicine, Dartmouth-Hitchcock Medical Center, Geisel School of \\ Medicine, Lebanon, NH, USA; ${ }^{b}$ Department of Pathology and Laboratory Medicine, \\ Dartmouth-Hitchcock Medical Center, Geisel School of Medicine, Lebanon, NH, USA
}

\section{Keywords}

Signet-ring cell carcinoma · Crohn's disease · Endoscopy .

\section{Abstract}

Signet-ring cell carcinoma is a rare adenocarcinoma, predominantly affecting the stomach and ovaries. Primary sites elsewhere are rarer. It is recognized that there is an increased cancer risk with the diagnosis of Crohn's disease. We report a patient with Crohn's disease who was diagnosed with signet-ring cell carcinoma in the setting of a Crohn's flare. Diagnosis was made with endoscopy. Treatment included laparoscopic-assisted right hemicolectomy with ileostomy with subsequent chemotherapy as an outpatient.

\section{Introduction}

Signet-ring cell carcinoma (SRCC) is a rare adenocarcinoma of epithelial origin, accounting for less than $0.5 \%$ of all malignancies [1]. It predominantly affects the stomach, with approximately a fourth of gastric cancers attributed to SRCC. However, SRCC has been known to affect other organs, such as the prostate, ovaries, pancreas, and large intestine to a much lesser extent $[2,3]$. In addition, only a small number of cases have been reported in patients with diagnosed Crohn's disease [4].It is generally known that inflammatory bowel disease (IBD) 


\section{Case Reports in Gastroenterology}

Case Rep Gastroenterol 2019;13:85-88

DOI: $10.1159 / 000493920$

(c) 2019 The Author(s). Published by S. Karger AG, Basel www.karger.com/crg

Feng et al.: Signet-Ring Cell Carcinoma Presenting as Hematochezia in a Patient with Crohn's Disease

increases a patient's risk for developing cancer along the gastrointestinal tract (GI), though the exact mechanism is poorly understood [5]. Theories include chronic inflammation causing dysplasia, use of immunosuppressants and biologics, and manipulation of the gut flora [6]. Herein, we present a case of SRCC involving the terminal ileum with concurrent Crohn's flare.

\section{Case Presentation}

A 44-year-old female with a history of Crohn's disease was admitted for progressive fatigue, chronic abdominal pain, and bright red blood per rectum. She was prescribed rivaroxaban approximately 2 weeks prior to this encounter for left calf tenderness determined to be secondary to a deep vein thrombosis. Physical examination on admission was notable for conjunctival pallor and right lower-quadrant tenderness on palpation of the abdomen with no distension; bowel sounds were present and normoactive. There was no appreciable fluctuation in weight in the past 12 months. Initial laboratory findings included a microcytic anemia (hemoglobin $6.6 \mathrm{~g} / \mathrm{dL}$ ), left-shift leukocytosis $(14.3 \mathrm{count} / \mu \mathrm{L})$, elevated sedimentation rate (ESR $45 \mathrm{~mm} / \mathrm{h}$ ), and elevated C-reactive protein (CRP $6.7 \mathrm{mg} / \mathrm{L}$ ). Rivaroxaban was stopped, and the patient was transfused with packed red blood cells with a goal of hemoglobin >7.0. The patient was continued on $20 \mathrm{mg}$ prednisone daily for Crohn's disease management with plans to start ustekinumab. Review of medical records showed an MRI enterography performed a month before, which suggested active Crohn's disease of the terminal ileum with increased dilatation of portions of the ileum proximal to the area of active disease; no fistula or abscesses were identified. In addition, a colonoscopy performed 1 year prior to this case presentation showed a stenotic but otherwise normally appearing ileocecal valve, preventing passage of the colonoscope and full visualization of the terminal ileum. Given her presentation and previous imaging findings, her symptoms were initially attributed to a lower GI bleed in the setting of rivaroxaban use. The patient had persistent anemia despite red blood cell transfusions prompting repeat colonoscopy. On visualization of the proximal cecum and terminal ileum, an ulcerating, partially obstructing, mass-like process was identified (Fig. 1). The mass was biopsied, which revealed SRCC with mucinous features. Additional laboratory tests included a carcinoembryonic antigen, which was within normal limits (CEA 1.8). Computed tomography of the chest, abdomen, and pelvis revealed no evidence of metastatic disease; radiographic measurement of the mass revealed approximately $8 \mathrm{~cm}$ in length at the distal ileum. The patient subsequently underwent laparoscopic-assisted right hemicolectomy with ileostomy, with the excised sample sent for gross pathology (Fig. 2a). Final pathological diagnosis was poorly-differentiated signet-ring cell adenocarcinoma (T4aN1) of the terminal ileum, ileocecal valve, and cecum (Fig. 2b). Molecular diagnostic was negative for RAS and BRAF genes. The patient was seen by medical oncology as an outpatient and was started on folinic acid, fluorouracil, and oxaliplatin (FOLFOX) adjuvant therapy.

\section{Discussion}

Cancer of the small intestine is a rare diagnosis. However, in patients with Crohn's disease, the relative risk of having a malignancy of the small intestine increases up to 30 times compared to the general population. Undoubtedly, abnormal imaging and symptom presentations should raise the specter of malignancy in individuals with IBD if the clinical context is ripe. In our patient's case, it was difficult to distinguish between malignancy and 
inflammation. MRI enterography has been shown to be useful in the diagnosis and management of IBD, but its role in deciphering between inflammatory flares in IBD and new malignancies continue to evolve [7, 8]. Although it is consensual knowledge that IBD increases the risk of GI malignancies, a proper modality or algorithm of screening or follow-up is not present in standard of care guidelines.

In addition, our patient had a previous colonoscopy, which showed abnormalities of the ileocecal valve most consistent with stricturing Crohn's disease. As mentioned above, inflammatory changes can be observed, but in our case, there was a quick development of malignancy between colonoscopy procedures. Such a rapidly developing entity is challenging to anticipate even with frequent procedures [9]. Given the various aggressiveness of GI malignancies that may develop in the setting of IBD, further investigation into improving the detection of malignancies early, either through more specific biomarker surveillance or increased sites of biopsy, is warranted.

Additionally, our patient was treated with the appropriate medical therapy for her Crohn's disease. Our team questioned whether the number of inflammatory flares predisposed her for her diagnosed malignancy [10]. Certainly, SRCC of the small intestine carries a rare diagnosis. In all, the current literature present neither patient studies of long-term medical therapies nor the impact of other comorbidities to prevent the development of malignancies. Though there are studies of chemoprevention of malignancy in Crohn's disease, longterm data are limited, and further investigation is needed [11].

\section{Statement of Ethics}

The patient was contacted after her hospital stay. She was told of the team's desire to publish her medical case in an academic journal. She was told that all information would be anonymized. She agreed to have her medical case be published. All authors listed were involved in the patient's care. The authors have no ethical conflicts to disclose.

\section{Disclosure Statement}

The authors have no conflicts of interest to declare.

\section{References}

1 Kumar V, Abbas A, Fausto N, Aster J. Robbins and Cotran Pathologic Basis of Disease. 9th ed. Philadelphia: Elsevier; 2014.

2 Fujita K, Sugao H, Gotoh T, Yokomizo S, Itoh Y. Primary signet ring cell carcinoma of the prostate: report and review of 42 cases. Int J Urol. 2004 Mar;11(3):178-81.

3 Balthazar EJ, Rosenberg HD, Davidian MM. Primary and metastatic scirrrhous carcinoma of the rectum. AJR Am J Roentgenol. 1979 May;132(5):711-5.

4 Paparo F, Piccardo A, Clavarezza M, Piccazzo R, Bacigalupo L, Cevasco L, et al. Computed tomography enterography and 18F-FDG PET/CT features of primary signet ring cell carcinoma of the small bowel in a patient with Crohn's disease. Clin Imaging. 2013 Jul-Aug;37(4):794-7.

5 Greenstein AJ, Sachar DB, Smith H, Janowitz HD, Aufses AH Jr. A comparison of cancer risk in Crohn's disease and ulcerative colitis. Cancer. 1981 Dec;48(12):2742-5.

6 Freeman HJ. Colorectal cancer risk in Crohn's disease. World J Gastroenterol. 2008 Mar;14(12):1810-1.

7 Moy MP, Sauk J, Gee MS. The Role of MR Enterography in Assessing Crohn's Disease Activity and Treatment Response. Gastroenterol Res Pract. 2016;2016:8168695. 


\begin{tabular}{l|l}
\hline Case Rep Gastroenterol 2019;13:85-88 \\
\hline DOI: 10.1159/000493920 & $\begin{array}{l}\text { @ 2019 The Author(s). Published by S. Karger AG, Basel } \\
\text { www.karger.com/crg }\end{array}$ \\
\hline
\end{tabular}

Feng et al:: Signet-Ring Cell Carcinoma Presenting as Hematochezia in a Patient with Crohn's Disease

8 Tolan DJ, Greenhalgh R, Zealley IA, Halligan S, Taylor SA. MR enterographic manifestations of small bowel Crohn disease. Radiographics. 2010 Mar;30(2):367-84.

9 Baxter NN, Goldwasser MA, Paszat LF, Saskin R, Urbach DR, Rabeneck L. Association of colonoscopy and death from colorectal cancer. Ann Intern Med. 2009 Jan;150(1):1-8.

10 Axelrad JE, Lichtiger S, Yajnik V. Inflammatory bowel disease and cancer: the role of inflammation, immunosuppression, and cancer treatment. World J Gastroenterol. 2016 May;22(20):4794-801.

11 Subramanian V, Logan RF. Chemoprevention of colorectal cancer in inflammatory bowel disease. Best Pract Res Clin Gastroenterol. 2011 Aug;25(4-5):593-606.

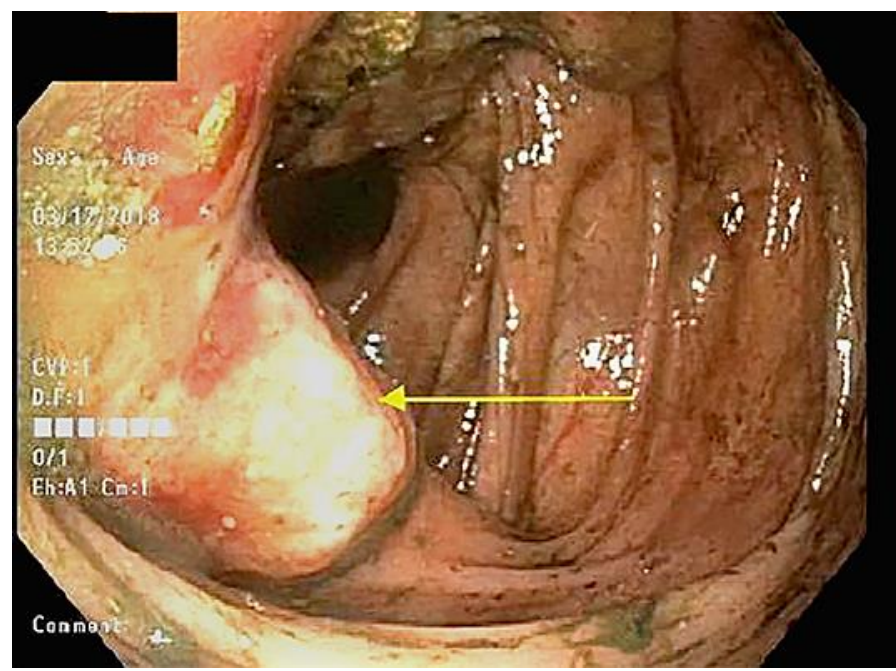

Fig. 1. The gross specimen displays an endophytic, ulcerating mass involving the terminal ileum, ileocecal valve, and cecum.
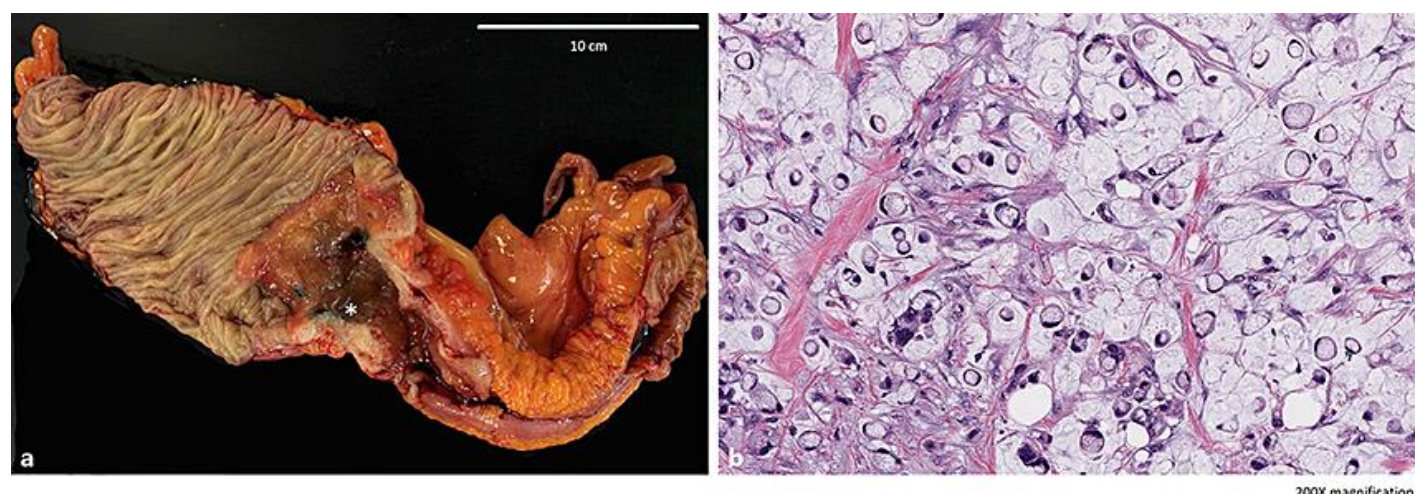

Fig. 2. a Gross pathology of the resected bowel. The asterisk shows the endophytic mass at the distal ileum b Tumor cells demonstrate signet-ring cell morphology with eccentrically displaced nuclei and abundant vacuolated cytoplasm. HE. $\times 200$. 